\title{
The Superiority or Integrity of Natural Law for Our Time
}

\author{
Nico P. Swartz ${ }^{1} \&$ Obonye Jonas ${ }^{1}$ \\ ${ }^{1}$ Department of Law, University of Botswana, Gaborone, Botswana \\ Correspondence: Nico P. Swartz, Department of Law, University of Botswana, Private Bag 00705, Gaborone, \\ Botswana. E-mail: nico.swartz@mopipi.ub.bw
}

\author{
Received: August 31, 2012 Accepted: September 17, 2012 Online Published: October 26, 2012 \\ doi:10.5539/ilr.v1n1p119 URL: http://dx.doi.org/10.5539/ilr.v1n1p119
}

\begin{abstract}
The idea of the two laws, one resting solely on human authority and the other claiming divine or natural origin and therefore entitled to supremacy over mere human law, has a long and chequered history, and still possesses vitality in the $21^{\text {st }}$ century. Human rights infringements by positive law, under the enactments of the Choice of Pregnancy Act 92 of 1996 and the South African Schools Act 84 of 1996, have led to a revival of natural law thinking. The aim of this paper will be to explore briefly the significance of natural law thinking in the past, to establish the forms in which it manifests itself in the present day, and to attempt to evaluate the contribution it may be capable of making to the problems of law in the modern world. Primarily, a theory of natural law needs to be undertaken to assist the practical reflections of those concerned to act, whether as judges, statesmen, citizens. The principles of natural law are traced out not only in religion, moral philosophy, and/or ethics and "individual" conduct, but also in political philosophy and jurisprudence, in political action, adjudication, and the life of the citizen. They require that authority be exercised, in most circumstances, according to the manner conveniently labelled as the Constitution or the "rule of law" and with due respect for human rights which embody the requirements of justice.
\end{abstract}

Keywords: natural law, positive law, divine commandment, corpus iuriscivilis, divine original

\section{Introduction}

Natural law is almost as old as philosophy itself. It can be described as a sort of recurring decimal in the history of thought. It had its great moments and its moments of eclipse, its flowering times and barren times, catabolic and anabolic periods. It has been declared dead, never to rise again from its ashes, but it has risen livelier than ever and buried its undertakers. There is, indeed, no doubt of the revival of interest in the natural law in our time. Natural law requires to be new in every age. Natural law should be shown to be sound and relevant in the conditions of our century.

During the $19^{\text {th }}$ century, human rights were stressed. Values like the right to life, dignity of the human person, the importance of personal freedom, toleration and the importance of the common good, were brought to the fore by the natural law theories. Crimes against humanity and against peace have been seen, as have abuses of power and the trappings of legality to the extent that the poverty of positivism (positive law) becomes evident. There must be something beyond the positive law to which an appeal can be made.

\section{Divine Characteristics of Natural Law}

Natural law betokened God's direct intervention into His creation. It is widely believed that in the oldest cultures it was the gods or God who "gave" law to humankind, by writing it in their hearts or by revealing it in divine scripture (Note 1).

As anthropomorphic images of deities took shape, the concepts of law and justice applying to human society became linked to these gods. Soon certain gods were considered specific guardians of law and judgement - gods who were invoked when it came to the violation of accepted norms (Note 2).

Thomas Aquinas emphasizes that natural law is the dictates imprinted by God in the human heart. According to Jan Schröder, Demosthenes concurs with Thomas Aquinas when he (Demosthenes) says: "Natural law is 'an inspiration and gift of God" (Note 3).

The terms "right" and "just" show law as something approved by the gods or God. The Sachnsenspiegel from the $13^{\text {th }}$ century states: "Gottistselber Recht. Darumistihm Rechtlieb." (God Himself is law) (Note 4). God is thus the 
omnipotent legislator. He is the source and legitimation of law. Natural law separate from God is inconceivable. All earthly judges are themselves ultimately subject to God's Last Judgement (Note 5).

Given that God is the creator and Lord of nature, natural law is in harmony with iusdivinum (spiritual law). It is the same everywhere, because it follows the same natural instincts (quod ubiqueinstinctunaturae... habetur). Accordingly iuspositivum (positive or man-made law) can be corrected and amended to comply with the tenets of iusnatural (Note 6).

Because of its divine character, natural law is absolutely binding and overrules all other laws. Whatever has been recognized by usage, or laid down in writing, if it contradicts natural law, must be considered null and void" (Note 7). This statement of Gratian is still further reinforced by his commentator: "it must be considered null and void because the Lord has said I am the Truth, not I am Custom or Constitution" (Note 8).

The essence of the doctrine of natural law maintains that there is an ordering of human relations different from positive law. Natural law is higher and absolutely valid and just because it emanates from the will of God. The will of God is-in the natural law doctrine-identical to nature insofar as nature is conceived of as created by God and the law of nature is an expression of God's will (Note 9).

The conviction that there are superior principles of right, or higher laws to which the ordinary civil rules made by man must conform and which necessarily place limits on the operation of such rules, is one of the most persistent ideas in the evolution of legal thought. These higher law concepts give direction to various processes of modern legal adjustments. The best-known and most influential form of the higher law doctrines centre around the term "natural law" or "law of nature" (Note 10).

\section{In Search for the Superiority of Natural Law: A Reflection of Sophocles' Play Antigone}

As early as the fifth century BCE, in Sophocles' play Antigone, the superiority of natural law over positive law (man-made law) seems to be confirmed. Creon, ruler of the city of Thebes, pronounces that Polynices, who has died in an attempt to win the city for himself, shall remain unburied and commends his body as a "dinner for the birds and for the dogs." In so stating, Creon is expressing the case for positive law or legal positivism, which uncompromisingly teaches obedience to the law of the state. Antigone, the sister of Polynices, defies her uncle's command and buries her brother. She says: "Nor did I think your orders were so strong that you, a mortal man, could over-run the gods' unwritten and unfailing laws. Nor now, nor yesterday's, they always live, and no one knows their origin in time. So not through fear of any man's proud spirit would I be likely to neglect these laws, draw on myself the gods' sure punishment" (Note 11). The struggle between Antigone and Creon represents the conflict between a higher moral law (natural law) on the one hand and man-made law (positive law) on the other hand.

Positive laws such as Creon's pronouncements that Polynices's body not to be buried, are not only of a transitory nature, but are the embodiment of the arbitrary power of rulers. This pronouncement or positive law enactment of Creon, is according to Augustine an unjust law and is therefore "no law at all." This reveals the imperfections of man-made laws and emphasises their inferiority (Note 12).

Thomas Aquinas considered a law unjust when it affronts natural law and such laws must never be obeyed, because he says, "we ought to obey God rather than men" (Note 13). In this, he metaphorically associates natural law with God, and positive law with man. The former is higher in value then the latter. Therefore, the law of nature as created by God unquestionably has a divine origin (Note 14). The laws of God (natural law) are superior in their obligatory power to all other laws. Positive laws are of no validity if contrary to them (Note 15).

By virtue of the Divine Original (God), natural law is regarded as superior to positive law.

\section{The Adulteration of Natural Law and Its Subsequent Desecration}

The concept of positive law has changed after 1650 and come to be construed as an order of a superior, namely a legislator. The order of the legislator no longer has to be rational as had previously been the case with regard to natural law. Law in general is now only "a decree by which a superior obliges a subordinate to act in accordance with his instructions," or "an order of a ruler who obliges his subordinates to adjust their actions to that order" (Note 17). It means the law of nature as divine commandment is regarded as a superfluous subtlety and therefore fits into a general concept of the law as the order of a legislator. Law of nature is therefore regarded as no longer "written in the heart" of man, but can be discerned through reason (Note 18). The author Christian Thomasius viewed natural law in 1705 as the order of a ruler or master. Schröder says about Thomasius, "he now wishes to classify the law of nature more as pieces of advice (consilia), than orders, that is to say no longer as laws in the strict sense" (Note 19).Schröder asserts that Johann Jacob Schmau $\beta$ doubts that natural law has the character of lex 
law. He cited Schmau $\beta$ as the latter is saying: "However, in a state of nature a man will regard God not as a legislator "but rather as his creator who has given him such a nature"" (Note 20).

Natural law becomes no longer regarded as a divine commandment. Wolff, for example, no longer sees an adequate basis for the law of nature in God but in the essence and in the nature of man and of things. Although he considers God as the author of natural law, he opines that God is not the supreme principle from which it is derived. Other authors, like Vattel, Montesquieu, Claproth, Achenwall, Höpfner and Nettelbladt concur with Wolff's contention and also eliminate God from the law of nature. Vattel says, "the natural laws are, in particular, those which oblige us by nature or whose basis is to be found in the essence and nature of man and in the essence and nature of things in general" (Note 21). Montesquieu exerts that the law of nature, "are so called because they spring solely and entirely from our character" (Note 22). According to Claproth, "when one perceives them (i.e. laws) from the nature of man and of the other things by which we are surrounded, one refers to them as natural laws" (Note 23).Asch enwall asserts, "a law is a body of rules which express an obligation and 'an obligation which man can discern from philosophical principles is referred to as a natural obligation" (Note 24).Hőpfner alleges that "a natural law is that which expresses a natural obligation" (Note 25). And Nettelbladt believes "a law is a 'rule' and "if one accepts that this rule is laid down by nature, the law is referred to as natural law"' (Note 26).

In the evaluation on these authors, the idea that the will and commandment of God as the actual basis of the law of nature is rejected. Vattel echoes that any attempt to prove that God's will is the basis of natural law must be attributed to the nature of man and things. Darjes asks the question, God has not revealed the law of nature to us directly and therefore, "how should I know that God so wishes?"(Note 27).

It is evident that these authors want to do away with God as the legislator of the law of nature. Natural law has become a mere product of reason from which God as legislator is eliminated and positive law becomes a mere order or commandment of the legislator which no longer has to be rational.

\section{The Imprint of Positive or Man-made Law}

In the High and Late Middle Ages the notion of what was "right" was consolidated by invoking God, for example, in 1525 a rebellious peasants after its appealing to local customs, usage and justice had failed has legitimized their acts through divine and natural law (Note 28).

Roman law, legitimized by tradition and theocracy, took hold from the $13^{\text {th }}$ century onwards. In spite of invoking God in the enforcement of the Corpus Iuris Civilis (533), Roman law took its legitimation from imperial authority. A need for a worldly legitimation of law was underpinned. It leaded to laws created by humankind (iuspublicum, iusgentium and iuscivile), which deviated from natural law to be legitimized (in the $6^{\text {th }}$ century) by Imperial will that decreed them valid (Note 29).

The reception of Roman law spawned a topos of legitimacy in the will of authorities. This was manifested by jurist popes of the $13^{\text {th }}$ century, who began to rule a world church through the targeted application of iuspositivum (positive law). The same development continued with the city authorities. From this concept or idea we can discern a process in which the legitimation of law shifted from the notion of theologically determined truth (veritas) to that of secularized will (voluntas), wherein natural law is replaced by positive or man-made law (Note 30).

As the foundations of natural law is undermined in the $16^{\text {th }}$ and $17^{\text {th }}$ centuries, so too did modern politics and the rule of law became emancipated from prescribed religious content. God no longer played a role. Natural law was rather based on the behaviour of political powers instead, and there was also an indent of the Christian element of natural law, to such an extent that the invocation of God in preambles of legislation became increasingly formulaic. This spurred a change in the foundations of legitimation in the sense that the state could also ordain something that was unjust and it would nevertheless be law (Note 31). It meant that unjust laws would be valid because it had been decreed valid.

The general direction would be that there has already been a formalistic legal position in the $17^{\text {th }}$ century. Medieval Roman law had already been taken hold and was considered a reasonable system of law. Positive (man-made) law consolidate those in power and had drawn its legitimation from sovereignty. These positive laws were "human" and have established positive norms. Legal norms soon became increasingly secularized until they eventually oriented themselves towards a temporal purpose (Note 32).

The God-given world of heaven and social order fell apart. This meant in principle a turning away from God. In other words although God remained prima causa, he could no longer had the "will" to intervene, even if he could. Natural law thus came to be perceived as something that could apply even without God (Note 33).

The legal crisis of the $16^{\text {th }}$ and $17^{\text {th }}$ centuries had crippled religiosity in natural law. The authority of theologians disintegrated and by the end of the $18^{\text {th }}$ century the world was perceived increasingly as pantheistically (Note 34 ). 
The early modern principality which was to become the paradigm of the era permitted the modernization of the medieval legal world. The notion of the "state as machine" now functioning according to the rules of the natural sciences. Even a "godless" tyrant was physically part of nature and of the social order. A natural law that opposed the laws of the state (positive or man-made laws) could become charged with revolutionary sentiment and therefore been rendered unjust (Note 35). For this reason, natural laws required no legitimation. They either held up against experimental attempts at falsification or they did not. Man-made or positive laws, on the other hand, are more dependent than ever on legitimation in a world in which it was no longer enough to invoke God. We got a scenario where the law of nature has disappeared (Note 36).

\section{Is There a Possibility of Co-operation between Natural and Positive Law?}

Klaus Luig states that Leibniz sought for legal rules that correspond to human nature created by God. The latter implies that these rules are to be transposed into positive law by the legislature. This means that positive or man-made law be based on a theologically founded theory of natural law. Luig opines along Leibniz thought that it was the law of nature that human should obey God's commandment of neighbourly love in order to work for the common weal (Note 37).

According to Luig, Leibniz would have mean that the rule of natural law has to be absolute and that even a judicial rule or law (positive law) has to be thus and not otherwise if everything is to be just and right (Note 38).

According to Luig, Leibniz's would have mean that everything that is in accordance with natural law should also apply in state (positive) law (Quicquidiurisnaturae ac diviniest, etiamiuriscivilishaberidebet) (Note 39). It means that natural law may also be complemented and altered by positive law.

What is vague in natural law is concretized, according to Leibniz, through positive law. Leibniz also asserts that the legislator can decree laws that deviate from natural law. This appears in cases where a subject of rights be renounced. In this sense, Leibniz would have professed or instruct that natural law take precedence where state law is lacking or incomplete. But, Leibniz exerts that the norm of natural law can be flexible if this is deemed equitable. In other words, natural law may be changed in the interests of fairness (Note 40).

Leibniz avers there are legal premises that could not be derived from natural law, but only from positive Roman law. This applies, for example, to the rule that, in the case of two persons bound to one another by verbal agreement, it is assumed that when one party is no longer present, the other will take his place. An example, furnished by Luig, arethe will and testament reading: "I bequeath to Titius and Caius a piece of land in equal parts." It means if Titius dies, then Caius receives his share as well. This entails that the ratio of natural law can be approached through the scientific commenting and expounding of positive law. The view is established that natural rules may be developed by scientific means on the basis of statutory provisions (Note 41). This principle applies to the sharing of damages also in a case in which neither the perpetrator nor the victim is to blame. For example, if one man's ox hurt another's that it dies, then heshall sell the live ox, and divide the money of it. They shall divide the dead ox. Leibniz believes this rule will aid the legislature. Luig cited Leibneiz justification of this rule: "If you weigh up the matter with care, then, in order to avoid displeasure and envious looks schehleaugen and inimitable attitudes... it will be just that we share the damage, whereby each shall think that he has unfortunately damaged the other or suffered damage. For if both are free of blame, the other has as much reason to complain that my interests were an obstacle for him as I have to think that he has confounded my interests" (Note 42).

This combinatorial analysis of natural law are valid in all fields of human knowledge and could be placed (or is already active) in the service of law-making in positive law.

\section{The Theory of State: The Principle of Obedience}

Each state came into being with reliance on the principle pactasuntservanda. According to this principle the citizens abdicate their rights in favour of the government who professes to rule over them. The concept is thus: the citizen surrender their rights and the government agree to protect these rights. This principle renders the citizens subject to the power which they have legitimately granted to the government. Van Blerk cites De Groot's passage from Sophocles' Antigone: "You must obey him whom the state has placed in power ..." (Note 43). She also cites another writer, Hobbes, who states: "No man in any commonwealth whatsoever has the right to resist him or them, on whom they have conferred their power ..." (Note 44).

The only sanction for governmental tyranny is that the rulers, instead of enjoying a happy afterlife, will suffer the "pain of eternal death" (Note 45). In congruence to this notion, the Institutio of Calvin (which is a comprehensive treatment of civil government and political authority), dating back to 1536, admonishes citizens to obey princes and officials. On those who bear the office of magistrate, it is inculcated that they have a commission from God. Calvin says: "Offices of rule are amongst the gifts of God ..." (Note 46) and rulers are the ministers of God "Dei 
enim minister est" (Note 47). Consequently, civil authority is not only lawful but the most sacred of all stations in mortal life. It, however, implies that the ruler must exercise his office justly, "for if they sin in any respect, not only is injury done to the men whom they wickedly torment, but they also insult God himself" (Note 48).

If authorities and rulers do exercise unrestrained power to the injury and detriment of the subjects, citizens owe reverence toward all rulers, even to the utmost (Note 49). An extremely high premium is put on the obedience of the citizens to positive law, in the sense that even when the citizens are tormented by a savage prince, they must still obey him, because obedience to the positive law is also God's command (Note 50).

The importance of positive law is being stressed: Obedience must be shown to civil rulers because they derive their authority from God. "Omnis enimpotestas a Domino Deoest" (Note 51). But kings, to be assured of obedience must rule justly and according to law (Note 52).

\section{The Limits of Obedience}

But blind obedience to positive law needs to be tested against reason and Gods love and protection for His creation, man and society. It is under this conviction that positive laws such as the Choice on Termination of Pregnancy Act 92 of 1996 and South African Schools Act 84 of 1996, are deem to be unjust and according to natural law, may under no circumstances be obeyed. These positive law enactments seem to ignore the natural law precepts of "Do not murder or do harm to any man," and thus disregard the common welfare of the citizens.

The state is a condition of our existence, Thomas Aquinas would say, and in some cases disobedience to it, concerning unjust laws, may be a duty. While resistance to the state might sometimes be necessary, there is in his thought no place for revolution against the state (Note 53). However, the other approach is that man is required to obey all superiors whether secular or ecclesiastical. There is no authority but by act of God. For Paul, the authorities are "God's agents" who are "working for your good" (Note 54). 1 Peter 2:13, 14, for example, admonishes obedience to superiors: "Submit yourselves to every human institution for the sake of the Lord ..." Earthly rulers receive their powers as a divine concession.

Positive law is to be obeyed also, but to the extent that it is concordant with natural law precepts. Offshoots of positive law such as the Termination of Pregnancy Act and the South African's School Act, which is contrary to natural law, need not to be obeyed (Note 55). The natural law contains all that makes for the preservation of human life (contrary to Termination of Pregnancy Act) (Note 56) and since man has a natural inclination to know the truth about God (religious education in Christian Education South Africa) (Note 57), the citizen must obey God (natural law) rather than man (positive or man-made law) (Note 58).

\section{Rule of Law}

Natural law and (the extension of it) to the positive law, also curtails the power of the state to tamper with a citizen's rights or freedoms. The latter is manifested in the Constitution and rule of law (Note 59). The Constitution and the rule of law (man-made laws), as mentioned earlier, must be obeyed, to the extent that it must not be contrary to the natural law. If the state injures the material interests of citizens, it breaches not only the constitution or rule of law but also the basic elements of the social contract. The term rule of law is to advocate respect for civil and political rights or even social and economic rights. In this regard it has both procedural and substantive components. The procedural component forbids arbitrary decision-making (for example, the admission of the Act, Termination on Pregnancyt) and the substantive component dictates that the government must respect the individual's basic rights, such as respect for human dignity, equality, and freedom (Note 60). In this regard, natural law and positive law complement each other.

The goal of natural law must be overall happiness or the "common good." The first and most fundamental principle of natural law is that "good is to be done and evil avoided," for example, do not kill your unborn child (Termination on Pregnancy Act) and educate and rear your children in a Christian manner (SA Schools Act). Other examples are: "One should not kill one's father;" and "God's precepts are to be obeyed" (Note 61). These principles are buttressed by two important natural law maxims, "suumcuiquetribuere" (give to everyone his due) and "neminemlaedere" (do not hurt another) (Note 62). The latter maxim entails that we must not hurt or kill the most vulnerable members of our community or state, such as the unborn. This notion is diametrically in opposition to the Termination of Pregnancy Act of South Africa. This notion is endorsed by the South African Constitution, Act 108 of 1996, in sections 9(1) and (3), 10 and 11. Section 9(1) prescribes that everyone is equal before the law and has the right to equal protection and benefit of the law, and subsection (3) states that the state may not unfairly discriminate directly or indirectly against anyone on the grounds of pregnancy and birth. According to section 10, the foetus also has an inherent dignity and the right to have its dignity respected and protected (Pinchin $v$ Santam Insurance Co Ltd 1963(2)SA 254 (W)).In terms of section11, the foetus has also a right to life. 
These precepts of the Constitution, in opposition to the statute Termination of Pregnancy Act and SA Schools Act) are offshoots of positive law, but are congruent with natural law theories and needs to be obeyed by everyone, including the state (the deviser of positive law).

\subsection{The Right to Life and Human Dignity}

The requirements of moral law, which emanate from natural law, state that one does not do to others that which one does not want done to oneself. The fact that you as an adult were not aborted when you were a foetus (embryo) signifies that you should do the same for your unborn baby. The inalienable right to life must be acknowledged and respected by both the state and the courts. Among these inalienable rights is each individual's right to life and physical integrity from the moment of conception until death. As soon as the state (positive law) denies or deprives a certain category of human beings protection, it denies them equality of all before the law, which is guaranteed in terms of Article 9 of the Constitution of South Africa 108 of 1996. In terms of Article 9(3) of the Constitution, the state (positive law) will discriminate against the foetus if it does not protect its right to life. In this regard, Article 9(3) says that the state would: “... unfairly discriminate directly or indirectly against anyone on one or more grounds, including ... age ... and birth," if it did not guarantee the foetus' right to life in terms of the Constitution. In this regard, the requirements of the Choice on Termination of Pregnancy Act 92 of 1996 should not be complied with, since it undermines the moral or natural law principle of the Constitution. Analogically said, Article 2 of the Constitution, which showed a natural tendency, expresses the principle of constitutional supremacy (like natural law enjoying supremacy over positive law). Article 8 of the Constitution also stipulates that the Bill of Rights of the Constitution supercedes all legislation (including the Choice on Termination of Pregnancy Act and the South African Schools Act). This approach is supported by the court case Executive Council of the Western Cape Legislature v President of the Republic of South Africa 1995(4) SA 877 (CC), in which it was determined: "Any law or conduct that is not in accordance with the Constitution ... will therefore not have the force of law." This is tantamount to the principle, extolled in this paper, that when positive law (enacted by the state, such as Choice on Termination of Pregnancy Act and SA Schools Act) contradicts natural law (although the Constitution is a form of positive law, it encompasses natural law elements, which strive for the preservation of human life and the practising of religious upbringing, which is the best guarantee for the protection and preservation of individual rights), the Constitution should, in my opinion, declare the Choice on Termination of Pregnancy Act unconstitutional. Man is considered to be a divine being on account of his soul (Note 63). The description of the unique value of humans in Psalm 8:5 is striking: "For thou hast made him but little lower than God, and crownest him with glory and honour. Man, as image bearer of God, is therefore endowed with individual rights that must be recognised by all, including the state. The practical implication of the natural law doctrine involves that man must be endowed with fundamental rights, from the foetal stage of pregnancy to adulthood. On the basis of this, man may not be deprived of his/her individual rights. By having created the human soul, God clothed humans in godliness. Human life, therefore, has a sacred and inviolable quality. This inviolate quality of human life is guaranteed by the Constitution of South Africa. Should there be any violation of this right, it would have far-reaching implications for political civil society.

Christian moral conservatives, such as John Finnis, have campaigned against any sort of right to terminate a pregnancy, at any stage, regardless of the costs to women. They also campaign against a right to withdrawal of life support when it is no longer wanted or needed, and against a right to die (voluntary euthanasia), no matter the suffering entailed in living. They maintain that human freedoms and choices do not extend to personal governance over life itself, because life is of supreme value - a gift from God. It is not ours to meddle with. It must be endured, if God so minded (Note 64).

The human being is "inviolable" and that human life is of infinite worth. The law must respect "the sanctity of human life." The invocation of "human sanctity" is intended to tell us that human beings are innately special. The term "sanctity" is borrowed from religious language and seems to have strong religious connotations. The very notion that human beings are of infinite value, seems rather implicitly religious with natural law undertones than secular (positive law) (Note 65).

\subsection{Human Dignity}

In modern times religious tolerance is a necessary precondition for political liberty. Section 15 of the Constitution of South Africa implies that religious communities should not be denied the right to practise their religion. In Christian Education SA, such communities sought an order declaring the provisions of section 10 of the South African Schools Act 84 of 1996, to be unconstitutional. Section 10 prohibits the administration of corporal punishment to pupils in a school context, and renders such act an offence which incurs the same sentence as would be imposed for assault (Note 66). The contention was that section 10 offended against the religious and cultural 
guarantees provided for in the South African constitution. The communities (appellants) rely on sections 15(1) (Note 67), 29(3) (Note 68), 30 (Note 69) and 31(1) (Note 70). Under sections 15 and 31(1), it was assumed by the applicant in Christian Education SA that corporal punishment was not inconsistent with any provision of the Bill of Rights as contemplated by section 31(2). It can therefore be asserted that section 10 of the Schools Act limits the parents' religious rights both under sections 31 and 15. The schools want to maintain an active Christian ethos and seek to provide for their learners an environment that is in keeping with their Christian faith. They assert that corporal punishment is an integral part of this ethos and that the blanket prohibition of its use in its schools invades their individual, parental, and community rights to freely practise their religion. Section 10 of the Schools Act should be declared unconstitutional and invalid in that it interferes with the right to freedom of religion and to cultural life to the extent that it prohibits corporal punishment. This notion is to be inconsistent with article 28 of the United Nations Convention on the Rights of the Child, of 20 November 1989. Article 28 of the convention accord recognition to the child and upholds the child's human dignity.

Corporal punishment is understood to be inseparable from their understanding of their Christian faith and an expression of their religion. Corporal punishment is a vital aspect of Christian religion and it is applied in the light of its Biblical context using biblical guidelines which impose a responsibility on parents for the training of their children. The appellant cited the following verses in the Bible as requiring its community members to use "corporal correction." In Proverbs 22:6, "Train up a child in the way it should go and when he is old he will not depart from it. Proverbs 22:15, "Foolishness is bound in the heart of a child, but the rod of correction shall drive it far from him." In Proverbs 19:18, "Chasten thy son while there is hope and let not thy soul spare for his crying." In Proverbs 23:13, 14, "Do not withhold discipline from a child, if you punish him with a rod he will not die. Punish him with a rod and save his soul from death."

These verses contend that corporal punishment is a vital aspect of Christian religion and that it is applied in the light of its Biblical context using Biblical guidelines which impose a responsibility on parents for the training of their children.

In MEC for Education, KwaZulu-Natal, and Others v Pillay 2008 (1) SA 474 (CC), the respondent approached the governing body of the school at which her daughter was a learner for an exemption from its code of conduct to allow her daughter (the learner) to wear a golden nose-stud to school. This is done in keeping with her Indian family tradition and culture. Wearing of a nose-stud is an expression of cultural identity. The governing body refused the respondent's application for exemption. The respondent approached the quality court for relief and was met with a finding that, although the school's conduct was prima facie discriminatory, the discrimination was not unfair. On appeal to the High Court it was found that the school's conduct was both discriminatory and unfair. The practice of wearing a nose-stud is a religious and cultural practice.

The school's code of conduct, coupled with the decision to refuse the learner an exemption from the code, was discriminatory on the grounds of both religion and culture in terms of section 6 of the Promotion of Equality and Prevention of Unfair Discrimination Act 4 of 2000. Under this Act, failure to take steps to reasonably accommodate the needs of people on the basis of race, gender, or disability amounted to unfair discrimination (Note 71). Reasonable accommodation was an important factor in the determination of the fairness of the discrimination (Note 72). Fairness required reasonable accommodation, and as regards the MEC for Education, the enquiry was subjective and the evidence showed that the wearing of a nose-stud was important to the learner as an expression of her religion and culture (Note 73). There was no evidence or no reason to believe that a learner who was granted an exemption from the provisions of the school's code of conduct would be any less disciplined, or that she would negatively affect the discipline of others. Refusing the learner an exemption therefore did not achieve the intended purpose (Note 74). Allowing the stud would not have imposed an undue burden on the school. A reasonable accommodation would have been achieved by allowing the learner to wear the nose-stud. The High Court's finding of unfair discrimination therefore had to be confirmed.

Now, positive law is enacted on behalf of the mass of men, but does not prohibit every vice from which virtuous men should abstain. Positive law is, therefore, either just or unjust. If just, they draw from the natural law, from which they derive and they are directed to the common welfare. On the other hand, positive laws may be unjust for two reasons. Firstly, when they are detrimental to human welfare as seen in the South African Schools Act. It is unjust in the sense that it prohibits a community's religious instruction to their children and that somebody was not permitted to express his or her religion and culture (the wearing of golden nose-stud in MEC for Education). It is tantamount to a ruler or state, who or which enacts laws which are burdensome to his/its subjects and which do not make for common prosperity, but are designed better to serve his/its own cupidity and vainglory. Such (positive) laws may be unjust through being contrary to natural law or divine goodness. These tyrannical laws (Choice on 
Termination of Pregnancy Act and South African Schools Act) are under no circumstances to be obeyed for it is said: "ObedireoportetDeomag is quam hominibus" (Note 75).

\section{Possible Co-operation between Natural and Positive Law}

Finnis quotes Kelsen who says: "It is a cardinal point of the historical doctrine of natural law... over two thousand years' that it attempts 'to found positive law upon a natural law delegation"' (Note 76). Finnis agrees with Kelsen who asserts that the legal validity of positive law is derived from its rational connection with natural law. Positive law is, according to them, a mere emanation of natural law.

The law of nature is not the only law which guides man on his way to perfection. Other laws, like the positive laws for example, are necessary. Positive laws must be established to rely on all the conclusions of natural law, and "to restrain evil men from wrongdoing by force and by fear" (Note 77).

The existence of natural law does not render the establishment of positive law superfluous. On the contrary, the necessity of positive law is being stressed (Note 78). Natural law encourages obedience to established rulers by reason of a natural order decreed by God Himself. Argued from a natural law premise, man possesses certain fundamental rights, as discussed above. These fundamental rights depend upon the belief in the existence of natural law in the strict sense and positive law in the broad sense. The United States Constitution (positive law), for example, is essentially a natural law document setting out the fundamental authority of the people under natural law and guaranteeing the natural rights of the citizens. The Constitution indeed carries a large part of the heritage of natural law into the modern world. Because they were embodied in the Constitution, these rights were given a special priority which enable the courts to treat them as superior to and thus prevailing over any legislation or other legal rule which conflicts with them (Note 79).

As for the relation between the natural law and the positive law, Thomas Aquinas argued, that legislation must be compatible with natural law tenets (Note 80). Legislation or statutes (positive law enactments) like Termination of Pregnancy Act and the SA Schools Act are not congruent with natural law sentiments. Thomas Aquinas looks on positive law as having the function of defining the natural law and providing the temporal sanctions which are otherwise lacking by natural law. For example, if we assume that there is a natural right to own property and that it is wrong to violate another's right, penalties for stealing have to be determined. It does not necessarily follow that every kind of infringement of the positive law should be prohibited and punished by the State. The legislator should have the common good in view, but the common good is not always best served by legal enactments. Thomas Aquinas, therefore, envisages a much closer relationship between natural law and positive legislation, but this does not mean that every moral precept must be made the subject of legislation by the State (Note 81). In Thomas Aquinas' view the interest of the common good constitutes the criterion.

\section{Conclusion}

It is evident that positive law enactments such as the Choice on Termination of Pregnancy Act and the South African Schools Act are under the context of natural law unjust. These positive law enactments ignore the natural law precepts of "Do not murder or do harm to any man," which is buttressed by the two statutes. The result is that the common welfare of the citizens is being jeopardized.

He paper stresses that positive law is to be obeyed to the extent that it is concordant with natural law precepts. As natural law pertains to all that makes for the preservation of human life, it needs to be supported by positive law. These two realms of law need not to become opposing to each other. Both are from God.

But if the state tampers with the citizen's right, like the right to life (fetus is regarded as human being from the moment of conception), it will become in contrast with natural law precepts. The government must respect the individual's basic rights, such as respect for human dignity. This idea is bolstered by the Constitution of South Africa. Section 9(3) of the South African Constitution entails that the state may not unfairly discriminate against anyone on the grounds of pregnancy and birth. According to section 10, the fetus also has an inherent dignity and the right to have its dignity respected and protected. These precepts or articles/sections of the constitution, which are also offshoots of positive law, are congruent with natural law theories and needs to be obeyed by everyone including the state.

\section{References}

Adams, D. M. (2000). Philosophical Problems in the Law (3rd ed.). California State Polytechnic University, Pomona. Wadsworth, United States.

Aquinas, T. Summa Theologiae.

Aqiunas, T. De Regimine Principum. Liber Primus. 
Calvin, J. (1996). Institutes. Book IV.

Choice on Termination of Pregnancy Act 92 of 1996.

Christian Education South Africa v Minister of Education of the Government of the RSA 1999(9) BCLR 951 (SE).

Cicero. De Legibus II, 4, 10.

Constitution of South Africa, 108 of 1996.

Copleston, F. C. (1972). A History of Medieval Philosophy. London: Methuen.

Currie, I., \& De Waal, J. (2005). The Bill of Rights Handbook (5th ed.). Lansdowne: Juta \& Company Ltd.

Davel, C. J. (2000). Introduction to Child Law in South Africa. Lansdowne: Juta \& Company Ltd.

D’Entréves, A. P. (1952). Natural Law: An Introduction to Legal Philosophy. London: Hutchinson University Library.

Justinian. (1995). Digesta. Executive Council of the Western Cape Legislature v President of the Republic of South Africa 1995(4) SA 877 (CC).

Holy, B. (1973, 1978, 1984). New International Version. International Bible Society.

Finnis, J. (1980). Natural Law and Natural Rights. Oxford: Clarendon Press.

Haines, C. G. (1930). The Revival of Natural Law Concepts. Cambridge: Harvard University Press.

Kelson, H. (1949). General Theory of Law and State. Cambridge: Harvard University Press.

Lloyd. D. (1964). The Idea of Law. Middlesex: Penguin Books Ltd.

MEC for Education. KwaZulu-Natal and Others v Pillay 2008(1) SA 474 (CC)

Naffien, N. (2009). Law's Meaning of Life. Philosophy, Religion and the Legal Person. Oxford and Portland, Oregon.

Prince v President of the Law Society, Cape of Good Hope 1998(8) BCLR 976 (C).

Promotion of Equality and Prevention of Unfair Discrimination Act 4 of 2000.

Rosmini, A. (1988). Principles of Ethics. Rosmini House, England.

Rosmini, A. (1991). Anthropology as an Aid to Moral Science. Rosmini House, England.

Rosmini, A. (1999). Essence of the Human Soul. Rosmini House, England.

South African Schools Act 84 of 1996.

Suid-Afrikaanse R. (1989). Werkstuk 25, Projek 58. Groeps- en Menseregte. Pretoria.

United Nations. (1989, November 20). Convention on the Rights of the Child.

Van Blerk, A. E. (1996). Jurisprudence: An Introduction. Durban: Butterworths Publishers (Pty) Ltd.

Wiltshire, S. F. (1992). Greece, Rome, and the Bill of Rights. Norman and London: Norman Publishing Division of the University.

\section{Notes}

Note 1. Romans 2: 15.

Note 2. Wilson (2008) 46.

Note 3. Jan Schrőder. Chapter 4. The Concept of (Natural) Law in the Doctrine of Law and Natural Law of the Early Modern Era.In Daston\&Stolleis. Natural Law and Laws of Nature in Early Modern Europe (2008): 57.

Note 4. Wilson (2008) 46.

Note 5. Wilson (2008) 47.

Note 6. Wilson (2008) 47.

Note 7. Decrr.Grat., I, viii, 2.

Note 8. D’Entréves Natural law 34.

Note 9. Hans Kelsen 1949:8.

Note 10. Charles Grove Haines 1930: 3. 
Note 11. Adrienne E Van Blerk 1996:1.

Note 12. Van Blerk 1996:11.

Note 13. Summa Theologiae 1-2, q. 96, a. 4.Acts 5:29.

Note 14. D’Entréves 1957:52.

Note 15. Adams 2000:60.

Note 16. Jan Schrőder (2008) 65.

Note 17. Jan Schrőder (2008) 65.

Note 18. Schröder (2008) 66.

Note 19. Schröder (2008) 66.

Note 20. Schrőder (2008) 67.Cited Vattel 1747: 4.

Note 21. Schrőder (2008) 67.Cited Montesquieu 1748: book 1, chap. 2, p. 12.

Note 22. Schrőder (2008) 67.Cited Claproth 1749: 33.

Note 23. Schrőder (2008) 67.Cited Aschenwall 1774: s. 49, p. 42.

Note 24. Schrőder (2008) 67.Cited Hőpfner 1780: s. 20, p. 13.

Note 25. Schrőder (2008) 67.Cited Nettelbladt 1785: s. 111, p. 58.

Note 26. Schrőder (2008) 67.Cited Darjes 1762: 259.

Note 27. Wilson (2008) 47.

Note 29. Wilson (2008) 48.

Note 30. Wilson (2008) 48.

Note 31. Wilson (2008) 50.

Note 32. Wilson (2008) 50.

Note 33. Wilson (2008) 51-2.

Note 34. Wilson (2008) 52.

Note 35. Wilson (2008) 52.

Note 36. Wilson (2008) 55.

Note 37. Klaus Luig. Chapter 11. Leibniz's Concept of jus natural and lexnaturalis - defined 'with geometric certainty.' In Lorraine Daston\&MichealStolleis.Natural Law and Laws of Nature in Early Modern Europe. (2008): 183-84.

Note 38. Luig (2008) 185.

Note 39. Luig (2008) 189-90.

Note 40. Luig (2008) 190.

Note 41. Luig (2008) 191.

Note 42. Luig (2008) 195.

Note 43. Van Blerk 1996:14.

Note 44. Van Blerk 1996:14.

Note 45. Van Blerk 1996:14.

Note 46. Calvin, Institutes, book iv, chapter xx, 4.

Note 47. Calvin, Institutes, book iv, chapter xx, 4.

Note 48. Calvin, Institutes, book iv, chapter xx, 6 .

Note 49. Calvin, Institutes, book iv, chapter xx, 29.

Note 50. Calvin, Institutes, book iv, chapter xx, 22.

Note 51. Rom. xiii, 1. Summa Theologiae 1-2, q. 93, a. 3, ad 2um. "For all power is from the Lord God."

Note 52. Haines 1930:16. 
Note 53. Wiltshire 1992:39.

Note 54. Wiltshire 1992:43.

Note 55. Summa Theologiae 1-2, q. 96, a. 4.

Note 56. Summa Theologiae 1-2, q. 94, a. 2.

Note 57. Summa Theologiae 1-2, q. 94, a. 2.

Note 58. Summa Theologiae 1-2, q. 96, a. 4. Acts v, 29.

Note 59. Iain Currie \& Johan De Waal 2005:10.

Note 60. Iain Currie \& Johan De Waal 2005:10-13.

Note 61. Adams 2000:51.

Note 62. Suid-AfrikaanseRegskommissie 1989: Werkstuk 25, Projek 58, Groeps- en Menseregte: 5.

Note 63. Rosmini 1999 (vol. 1):123.

Note 64. Naffien 2009:116.

Note 65. Naffien 2009:100.

Note 66. Section 10 of the South African Schools Act provides: (1) No person may administer corporal punishment at a school to a learner. (2) Any person who contravenes subsection (1) is guilty of an offence and liable on conviction to a sentence which could be imposed for assault."

Note 67. Section 15(1): Everyone has the right to freedom of conscience, religion, thought, belief and opinion.

Note 68. Section 29(3): Everyone has the right to establish and maintain at their own expense, independent educational institutions.

Note 69. Section 30: Everyone has the right to use the language and to participate in the cultural life of their choice.

Note 70. Section 31(1): Persons belonging to a cultural, religious or linguistic community may not be denied the right, with other members of that community- (a) to enjoy their culture, practice their religion and to use their language, and (b) to form, join and maintain cultural, religious and linguistic associations and other organs of civil society.

Note 71. MEC for Education, para 72 at 500A-B.

Note 72. MEC for Education, para 77 at 502B.

Note 73. MEC for Education, para 88 and 90 at 505B-C and 506B.

Note 74. MEC for Education, para 101-102 at 508E-F.

Note 75. Summa Theologiae 1-2, q. 96, a. 4. "We must obey God rather than man."

Note 76. John Finnis 1980:27. Kelsen 1949:412

Note 77. D’Entréves 1952:44.

Note 78. Van Blerk 1996:13.

Note 79. Denis Lloyd 1964:84.

Note 80. Summa Theologiae 1-2, q. 95, a. 2.

Note 81. Copelston 1972:190-1. 